\title{
Gene rearrangement detection by next-generation sequencing in patients with non-small cell lung carcinoma
}

\author{
Aneta Brisudova ${ }^{a}$, Jozef Skarda ${ }^{a}$
}

Non-small cell lung carcinoma (NSCLC) is the leading cause of cancer-related deaths worldwide. Various molecular markers in NSCLC patients have been developed, including gene rearrangements, currently used in therapeutic strategies. With increasing number of these molecular biomarkers of NSCLC, there is a demand for highly efficient methods for detecting mutations and translocations in treatable targets. Those currently available U.S. Food and Drug Administration (FDA) approved approaches, for example imunohistochemisty (IHC) and fluorescence in situ hybridization (FISH), are inadequate, due to sufficient quantity of material and long time duration. Next-generation massive parallel sequencing (NGS), with the ability to perform and capture data from millions of sequencing reactions simultaneously could resolve the problem. Thanks to gradual NGS introduction into clinical laboratories, screening time should be considerably shorter, which is very important for patients with advanced NSCLC. Moreover, only a minimum sample input is needed for achieving adequate results. NGS was compared to the current detection methods of ALK, ROS1, c-RET and c-MET rearrangements in NSCLC and a significant match, between IHC, FISH and NGS results, was found. Recent available researches have been carried out on a small numbers of patients. Verifying these results on larger patients cohort is important. This review sumarizes the literature on this subject and compares current possibilities of predictive gene rearrangements detection in patients with NSCLC.

Key words: non-small cel lung carcinoma, gene rearrangement, next-generation sequencing, immunohistochemistry, fluorescence in situ hybridization

Received: November 11, 2019; Revised: March 10, 2020; Accepted: March 19, 2020; Available online: April 6, 2020 https://doi.org/10.5507/bp.2020.015

(c) 2020 The Authors; https://creativecommons.org/licenses/by/4.0/

${ }^{a}$ Department of Clinical and Molecular Pathology, Faculty of Medicine and Dentistry, Palacky University Olomouc, Czech Republic Corresponding author: Aneta Brisudova, e-mail: brisudova.aneta@seznam.cz

\section{INTRODUCTION}

Lung carcinoma is a heterogenous disease and a leading cause of death in both men and women worldwide ${ }^{1}$. It can be divided into two groups. The first is a small cell lung carcinoma (SCLC) and the second is non-small cell lung carcinoma (NSCLC). Non-small cell lung carcinoma accounts for approximately $85-90 \%$ of all lung cancer. It is divided into adenocarcinomas (40-50\%), squamous carcinomas (20-30\%), large cell carcinomas and other uncommon carcinomas. Adenocarcinoma is the most common subtype diagnosed in smokers as well as nonsmokers. SCLC patients are more sensitive to systemic chemotherapy and radiotherapy than NSCLC patients in the first months following diagnosis. However, there is later disease relapse $\mathrm{e}^{2-5}$. For this reason, the used therapy is targeted and based on tyrosine kinase inhibitors (TKI) or monoclonal antibody ${ }^{6}$. However, despite the current treatment approaches, the overall survival rate over 5 years is only $15 \%$. Early diagnosis together with the detection of treatable targets however significantly contribute to prolongation of patient life span. Lung cancer is often diagnosed in the advanced stages. At least $40 \%$ of these cases are diagnosed with advanced distant metastases. For this reason, it is crucial to implement new diagnostic methods $^{7-9}$.

\section{Clinical biomarkers currently used in therapeutic} strategies for NSCLC

With the expansion of modern genetic and molecular techniques, various diagnostic and therapeutic procedures have been progressively developed. Basic diagnostic molecular targets in NSCLC include the first discovered somatic mutation in the human epidermal grow factor receptor $(E G F R)$ (ref. $\left.{ }^{10,11}\right)$, anaplastic lymphoma kinase $(A L K)$, reactive oxygen species $1(R O S I)$ proto-oncogene, tyrosine-protein kinase receptor Ret (c-RET) and mesenchymal epithelial transition factor/hepatocyte growth factor receptor ( $c-M E T)$ belonging to tyrosine kinase receptors. Discovery of these markers has led to the extension of targeted therapy using tyrosine kinase inhibitors.

The epidermal growth factor receptor gene is located on chromosome 7 ( $7 \mathrm{p} 11.2)$ and encodes a type I transmembrane growth factor tyrosine kinase receptor ${ }^{12}$. Tyrosine kinase activity may be dysregulated by oncogenic gene mutations. In NSCLC, gain of function or activating mutations of EGFR cause overexpression and constitutive kinase activity ${ }^{13}$. These mutations are detected by polymerase chain reaction-amplified genomic DNA in the first step of NSCLC molecular characterization ${ }^{14,15}$.

The anaplastic lymphoma kinase gene is located on chromosome 2 ( 2 p23) and identified in the nervous system during embryogenesis but its expression decreases postnatally. $A L K$ was originally identified in 1994 as an 
oncogene in anaplastic large cell lymphomas (ALCL). The C-terminal cytoplasmatic domain of $A L K$ fusion to the N-terminal of nucleophosmin $(N P M)$ has been identified in $40-60 \%$ of ALCLs. The fusion generates a gene product $\mathrm{p} 80^{\mathrm{NPMALK}}$, a protein that plays a key role in protein shuttling ${ }^{16-19}$. ALK rearrangement was later associated with $5-6 \%$ of NSCLCs. It is more common in younger patients (median age 55 years), never or light smokers $(70 \%)$ diagnosed with adenocarcinoma ${ }^{7}$. More than 30 fusion partners have been identified, e.g. KIF5B (kinesin family member 5B), $C U X 1$ (cut-like homeobox 1) ( ref. $^{20}$ ), STRN (striatin) ( ref. $^{21}$ ), DCTN1 (dynactin-1), SQSTM1 (sequestome-1) (ref. ${ }^{22}$ ), etc. (ref. $\left.{ }^{23}\right)$. The most common partner is EML4 (Echinoderm microtubule-associated protein-like 4). EML4-ALK fusion, found in 2007, causes constitutive anaplastic lymphoma kinase activity leading to the oncogenic pathway in NSCLC. This ALK fusion protein is an appropriate therapeutic target of TKI (ref. ${ }^{24}$ $\left.{ }^{26}\right)$. Either alone or in combination with systemic therapy, patients have very favorable responses. The FDA have approved tyrosine kinase ALK inhibitors, crizotinib, alectinib and ceritinib. Crizotinib, registered in 2010, was the first drug for ALK positive fusion treatment ${ }^{27-29}$.

The success of Crizotinib in ALK-positive patients initiated the effort to find new oncogenic fusions in NSCLC. This led to identification of new oncogenic fusions involving ROS1, c-RET and c-MET. ROS1 is located on chromosome 6 (6q22), whose structure was identified in 2003. Rearrangement of the ROS1 gene was first discovered in 2007 (ref. ${ }^{30}$ ). Using diverse genotyping techniques, ROS1 mutations were identified in 1-2\% of NSCLC (ref. ${ }^{31}$ ). Detection of ROS1 rearrangement is critical for optimal targeted therapy. Initially it was identified in a glioblastoma cell line ${ }^{32}$ where intrachromosomal



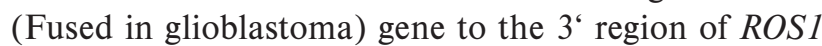
(ref. ${ }^{33}$ ). Recently, more fusion partners have been found, e.g. $E Z R$ (Ezrin) (ref. $\left.{ }^{34}\right), S D C 4$ (Syndecan-4) (ref. $\left.{ }^{35}\right)$, CCDC6 (Coiled-Coil Domain Containing 6) (ref. ${ }^{36}$ ) and $C D 74$ (Cluster of differentiation 74) which is the most common one in NSCLC (ref. ${ }^{37}$ ).

Another treatable target is $c-R E T$ (rearranged during transfection) proto-oncogene. Its fusion is found in about $1-2 \%$ of NSCLC $\left(\right.$ ref. $\left.^{38}\right)$. Initially it was discovered in thyroid carcinoma ${ }^{39}$. Later, in 2012, it was identified in lung ${ }^{40}$. The $c$-RET gene is located on chromosome 10 (10q11.2) and encodes a single pass transmembrane protein with a typical intracellular tyrosine kinase domain. It consists of three domains and shares $37 \%$ amino acid sequence homology with the ALK kinase domain ${ }^{41}$. It plays an important role in organogenesis and development of the enteric nervous system. At least 7 fusion partners were identified in adenocarcinomas, including the best characterized KIF5B (Kinesin family member $5 \mathrm{~B}$ ) followed by CCDC6 and $N C O A 4$ (Nuclear receptor coactivator 4) (ref. ${ }^{42,43}$ ). Wang $^{44}$ examined RET positive, younger, never smoker patients with early lymph node metastases and poorly differentiated tumors. As well as other driving mutations, $R E T$ rearrangement appears to be specifically associated with NSCLC and may be a targetable oncogenic driver ${ }^{45}$.
The last mentioned biomarker is mesenchymal epithelial transition factor tyrosine kinase. It is located on chromosome 7 (7q31) and is important for embryonic development and organogenesis ${ }^{32,46}$. c-MET and its natural ligand hepatocyte growth factor (HGF) are involved in MET-expressing epithelial cells in an endocrine or paracrine fashion. c-MET dysregulation is usually based on gene amplification (overexpression) and MET exon 14 splice site mutation. The $c-M E T$ gene mutation is an important mechanism and is detectable in $5-22 \%$ of NSCLCs $\left(\right.$ ref. $\left.^{47}\right)$. Constitutevely activated MET, receptor tyrosine kinase, promotes tumor angiogenesis, cell invasion and metastasis propagation in NSCLC ( ref. $^{48}$ ). MET acts as intracellular transducer by recruiting and activating several effectors, including PI3K (phosphatidylinositol 3-kinase), RAS (rat sarcoma), Gab1 (GRB2 [Growth factor receptor-bound protein 2]-associated-binding protein 1) and STAT3 (Signal transducer and activator of transcription 3 ) $\left(\right.$ ref. $\left.^{49-53}\right)$.

\section{Next-generation sequencing}

NGS, sometimes called massive parallel sequencing, is becoming an important part of diagnostic and therapeutic practice in NSCLC. This is due to the quality and quantity of the available tumor biopsy or cytology material, that is not always sufficient for performing currently approved immunohistochemistry (IHC) and fluorescence in situ hybridization (FISH) approaches. Due to the importance of molecular testing of lung cancer patients, pathologists have to remember to save material for subsequent analyses. Greater samples quantities are thus needed to analyze a required number of molecular markers than is usually available. In addition, the least invasive biopsy should be performed and only small samples with few cells are obtained. Biopsies are invasive examinations, technically difficult, very risky and painful for patients. NGS is an emerging technology with the potential to overcome these limitations. More recent studies indicate that only a minimum sample input, about 10ng DNA/ RNA corresponding to approx. 1000-1500 human cells, is necessary for achieving adequate results ${ }^{54}$. Thanks to these possibilities, rare fusion partners of $A L K$ have been found. With the introduction of NGS to molecular genetics and molecular diagnostics by allowing formalin-fixed paraffin embedded (FFPE) tissues to be screened, there are new efficiency and time duration options available. This technology is being introduced at new laboratories requiring accurate and timely results which guide patient therapy decisions ${ }^{20-22,55-58}$. NGS for SNVs, INDELs and CNVs detection is based on DNA sequencing, in contrast to RNA-seq developed mainly for detection of gene fusions. Apart from fusions, it is capable of detecting an aberrant splice variant of exon 14 skipped $\operatorname{MET}$ ( ref. $^{59}$ ). Both DNA and RNA sequencing appproaches have indisputable advantages. While DNA sequencing in preferable for testing mutations from non-transcribed regions, such as in a promoter, RNA sequencing is more suitable, for example, for intron-intron break testing. This should change the transcription product due to aberrant fusion and/or enhance gene expression. Currently, there is more 
evidence from DNA sequencing in molecular pathology than RNA sequencing. Many patients are not tested for the required number of molecular markers because of the high demand on time, money, equipment and sample quantity. Multicategorical DNA/RNA testing is hence increasingly needed. Separately prepared samples under specific conditions and the different approaches in DNA and RNA sequencing procedures, which also necessiate differently prepared samples are the main obstacles in simultaneous testing. Recent studies to create an optimal panel for simultaneous DNA and RNA sequencing in NSCLC patients have achieved useful results covering more than hundred RNA and more than fifty DNA targets and this could be an optimal solution ${ }^{60}$. The two NGS platforms currently used in clinical laboratories, are the Illumina and the IonTorrent. The Illumina is based on sequencing by synthesis with the small flow-cells in the fast sequencing process (illumina.com). The IonTorrent technology is based on emulsion PCR using native dNTP chemistry that releases hydrogen ions, causing $\mathrm{pH}$ modification during DNA synthesis (thermofisher.com) (ref. ${ }^{61}$ ).

Application of NGS technology in tumor molecular characterization led to databases such as The Cancer Genome Atlas (TCGA) and International Cancer Genome Consortium (ICGC) creation, that are valuable resources for exploring the impact of mutations in the human cancer genome. In recent years, it has been shown that larger mutation screenings are useful in the management of NSCLC. NGS is now progressively replacing single gene testing methods ${ }^{62}$.

\section{Gene rearrangement detection in NSCLC patients}

FISH assay with dual-labeled break apart probes for selecting patients for TKI therapy was used recently. Later, carefully validated IHC was found to be an appropriate method for $A L K$ and ROS1 rearrangement. A number of studies have shown that $A L K$ FISH and IHC results did not match, but patients with FISH negative and IHC positive results may also benefit from ALK-TKI therapy ${ }^{26,63}$. Moreover, IHC is relatively inexpensive and is performed routinely in most diagnostic laboratories. However, a serious disadvantage of both FISH and IHC results is the time duration and large sample size requirement. This is surmountable using next-generation sequencing. NGS is technology with the ability to perform and capture data from millions of sequencing reactions simultaneously. All NGS platforms are able to catch the individual sequence of hundreds of millions of molecules at the genome or transcriptome level ${ }^{28,64-67}$. One obstacle to initiating NGS in routine practice is the high initial costs as it method is currently more expensive than the methods above. With increasing numbers of patients tested by NGS, there is an assumption that costs will be sustainable. The cost of an NGS gene panel approach the cost of single gene testing by IHC/FISH owing to the testing time of each target separately and trained staff. Implementation of NGS would create inter laboratory collaboration, sharing of results, automation and improved quality of genetic predictive and diagnostic medicine. This reasoning underlies the rational for believing why the costs will drop in the near future for laboratories with NGS in clinical predictive practice ${ }^{68}$.

Velizheva et al. describe fusion detection assays (FISH, IHC, NGS) of EML4-ALK and EZR-ROS1 in NSCLC and demonstrate the reliability of NGS in comparison to previously FDA approved FISH and IHC (ref. ${ }^{65}$ ). NGS results of ALK fusion had 100\% match with IHC assay as expected. NGS+ FISH- patients received crizotinib treatment with durable progression-free survival providing evidence for the validity of the NGS results. Further studies confirmed the high agreement (over 98\%) of NGS testing with IHC (Tab. 1) (ref. ${ }^{26,67}$ ). IHC is still the most used and remains the gold standard in $A L K$ rearrangement detection. NGS appears to be a reliable technique for assessing ROS1 rearrangement, offering the above advantages. NGS has $100 \%$ match to FISH, which is routinely used in diagnostic laboratories ${ }^{66}$.

Discovery of fusion gene KIF5B-RET from a largescale sequencing led to the discovery of a novel therapeutic target for adenocarcinomas ${ }^{69}$. Although IHC is an effective detection method for $A L K$ and ROS1, for RET detection it has been disappointing on account of false positive/negative results. FISH is highly sensitive and represents the gold standard of RET rearrangement detection, but it is non specific with respect to RET fusion partners $^{44,65}$. Their main limitation is confounding of re-

Table 1. Current comparison of NGS with IHC, FISH and RT-qPCR in detection of gene rearrangement in NSCLC.

\begin{tabular}{|c|c|c|c|c|c|}
\hline Gene & Number of patients & Method & Comparison & Match (\%) & Ref. \\
\hline \multirow[t]{3}{*}{$A L K$} & 51 & NGS & IHC & 98 & 26 \\
\hline & 52 & NGS & IHC & 100 & 65 \\
\hline & 7 & NGS & IHC & 98 & 67 \\
\hline \multirow[t]{2}{*}{ ROS1 } & 52 & NGS & IHC, FISH & 100 & 65 \\
\hline & 7 & NGS & FISH & 100 & 66 \\
\hline$c-R E T$ & 1 & NGS & FISH & 100 & 65 \\
\hline$c-M E T$ & 51 & NGS & RT-qPCR & 97.4 & 74 \\
\hline
\end{tabular}

$A L K$ - Anaplastic lymphoma kinase, $c-M E T$ - Mesenchymal epithelial transition factor, $c$-RET - Tyrosine-protein kinase receptor Ret FISH -Fluorescence in situ hybridization, IHC - Immunohistochemistry, NGS - Next-generation sequencing, ROS1 - Reactive oxygen species 1, RTqPCR - Quantitative polymarase chain reaction with reverse transcription 
sults from FFPE samples with degraded RNA. Finally, NGS provides accurate and sensitive profiling of the RET gene when there is a lack of tumor material. It is possible to catch mutations of $<0.1 \%$ mutant allele fraction with $>99.9999 \%$ specificity. On the other hand, complexicity, difficulties in interpretation and high cost are still problematic $^{70-72}$.

The frequency of MET exon 14 skipping (METex14) is comparable to other gene rearrangements of interest. Recent research on METex 14 detection compared RTqPCR with Sanger sequencing and NGS for future diagnostic use. The Sanger sequencing assay was proven to be least specific mainly to false negative results, while a METex14 mutation was found by NGS (Tab 1.). NGS shows high specificity and sensitivity, as well as RT-qPCR, which is currently routinely used in clinical practice ${ }^{73,74}$.

These recent studies are focused on improving NGS as diagnostic method in NSCLC screening. Analysis of gene rearrangement with very small sample input, only 10ng, was carried out. However, NGS has not been studied in sufficient number of patients and optimized for current conditions and needs of clinical laboratories, which is inevitable for introduction into clinical practice.

\section{CONCLUSION}

The importance of recognizing molecular subtypes is paramount for targeted therapy of $A L K, R O S 1, c-R E T$ and c-MET by specific tyrosine kinase inhibitors. With increasing numbers of molecular biomarkers in NSCLC for targeted therapy determination, provision of sufficient amount of tumour tissue is often problematic. Moreover, there is a requirement to diagnose the patient with advanced lung carcinoma as soon as possible. Current diagnostic methods do not meet the charasteristic of present time because the processing of results takes approximately 15 days. Therefore, there is a constant effort to increase diagnostic yield, to reduce the time duration, and to minimalize the sample DNA/RNA input ${ }^{75}$. In addition, new fusion partners should be detected by NGS. It is known, that different ALK-fusion partners can affect diverse ALK-TKI efficiency. Patients with some variants have significantly longer PFS with TKI. Moreover, some ALK-fusion partners led to primary resistence to crizotinib $^{76,77}$. Identification of new ALK, ROS1, c-RET and $c$ $M E T$ fusion partners can define personalized treatment more precisely.

This work summarizes currently available detection assays in NSCLC patients and compares individual methods among themselves. The results show, that NGS represents the future posibility of rapid diagnostic approach. Howewer, comparison of NGS with FISH, IHC and RTqPCR has been carried out on a small numbers of patients (Tab 1). Therefore, it is important to verify these results on larger patients cohorts to demonstrate the sensitivity, specificity and reliability of next-generation sequencing for diagnostic purposes.

\section{Search strategy and selection criteria}

Our research strategy was aimed at evaluating studies on the detection methods of selected gene rearrangement in NSCLC patients to determine the optimal method for overcoming the existing failures. Scientific articles from 1985 to 2019 were searched using the PubMed and Google scholar. The search terms used were, "ALK NSCLC", "ROS1 NSCLC", "c-RET NSCLC“, "c-MET NSCLC", "IHC, FISH, NGS in NSCLC" and "gene rearrangement detection in NSCLC“.

\section{ABBREVIATIONS}

ALCL, Anaplastic large cell lymphomas; ALK, Anaplastic lymphoma kinase; CCDC6, Coiled-coil domain-containing protein 6; CD74, Cluster of differentiation 74; c-MET, Mesenchymal epithelial transition factor; c-RET, Tyrosineprotein kinase receptor Ret; CUX1, Cut-like homeobox 1; DCTN1, Dynactin-1; EGFR, Epidermal grow factor receptor; EML4, Echinoderm microtubule-associated protein-like 4; EZR, Ezrin; FDA, U.S. Food and Drug Administration; FFPE, Formalin-fixed paraffin embedded; FIG, Fused in glioblastoma; FISH, Fluorescence in situ hybridization; Gab1, GRB2 [Growth factor receptorbound protein 2]-associated-binding protein 1; HGF, Hepatocyte growth factor; ICGC, International cancer genome consortium; IHC, Immunohistochemistry; KIF5B, Kinesin family member 5B; NCOA4, Nuclear receptor coactivator 4; NPM, Nucleophosmin; NSCLC, Non-small cell lung carcinoma; NGS, Next-generation sequencing; PI3K, Phosphatidylinositol 3-kinase; RAS, Rat sarcoma; ROS1, Reactive oxygen species 1 protooncogene; SCLC, Small cell lung carcinoma; RT-qPCR, Quantitative polymarase chain reaction with reverse transcription; SDC4, Syndecan-4; SQSTM1, Sequestome-1; STAT3, Signal transducer and activator of transcription 3; STRN, Striatin; TCGA, The Cancer Genome Atlas; TKI, Tyrosine kinase inhibitors.

Author contributions: AB: literature search and manuscript writing; JS: corrections and final approval.

Conflict of interest statement: None declared.

\section{REFERENCES}

1. Siegel RL, Miller KD, Jemal A. Cancer statistic, 2019. CA Cancer J Clin 2019:69(1):7-34.

2. Schiller JH, Harrington D, Belani CP, Langer C, Sandler A, Krook J, Zhu J, Johnson DH. Comparison of four chemotherapy regimens for advanced non-small lung cancer. N Engl J Med 2002;346(2):92-8.

3. Skřičková J, Špelda S, Kaplnová J, Merta Z, Pálková I, Salajka D, Vomela J. Bronchogenní ka rcinom. In: Adam Z, Vorlíček J, edit. Speciální onkologie. Brno: Masarykova Univerzita 2002;34-53.

4. Sun S, Schiller JH, Gazdar AF. Lung cancer in never smokers--a different disease. Nat Rev Cancer 2007;7(10):778-90.

5. Zappa C, Mousa SA. Non-small cell lung cancer: current treatment and future advances. Transl Lung cancer res 2016;5(3):288-300.

6. Goldstraw P, Ball D, Jett JR, Le Chevalier T, Lim E, Nicholson AG, Shepherd FA. Non-small cell lung cancer. Lancet 2011;378(9804):1727-40. 
7. Sun Y, Ren Y, Fang Z, Li C, Fang R, Gao B, Han X, Tian W, Pao W, Chen $\mathrm{H}$, Ji $\mathrm{H}$. Lung adenocarcinoma from East Asian never-smokers is a disease largely defined by targetable oncogenic mutant kinases. J Clinic Oncol 2010;28(30):4616-20.

8. Noone AM, Cronin KA, Alterkruse SF, Howlader N, Lewis DR, Petkov VI, Penberthy L. Cancer incidence and survival trends by subtype using data from the surveillance epidemiology and end results program, 1992-2013. Cancer Epidemiol, Biomarkers Prev 2017;26(4):632-41.

9. Torre LA, Siegel RL, Ward EM, Jemal A. Global cancer incidence and mortality rates and trends--an update. Cancer Epidemiol, Biomarkers Prev 2016;25(1):16-27

10. Lynch TJ, Bell DW, Sordella R, Gurubhagavatula S, Okimoto RA, Brannigan BW, Harris PL, Haserlat SM, Supko JG, Haluska FG, Louis DN, Christiani DC, Settleman J, Haber DA. Activating mutations in the epidermal growth factor receptor underlying responsiveness of nonsmall-cell lung cancer to gefitinib. N Engl J Med 2004;350(21):212939.

11. Paez JG, Jänne PA, Lee JC, Tracy S, Greulich H, Gabriel S, Herman $P_{,}$ Kaye FJ, Lindeman N, Boggon TJ, Naoki K, Sasaki H, Fuji Y, Eck MJ, Sellers WR, Johnson BE, Meyerson M. EGFR mutations in lung cancer: correlation with clinical response to gefitinib therapy. Science 2004;304(5676):1497-500.

12. Yarden $Y$, Sliwkowski MX. Untangling the ErbB signalling network. Nat Rev Mol Cell Biol 2001;2(2):127-37.

13. Ciardiello F, Tortora G. EGFR antagonists in cancer treatment. New Engl J Med 2008;358(11):1160-74.

14. Eberhard DA, Giaccone G, Johnson BE, Non-small-cell lung cancer working group. Biomarkers of response to epidermal growth factor receptor inhibitors in non-small-cell lung cancer working group: standardization for use in the clinical trials setting. J Clin Oncol 2008;26(6):983-94.

15. Da Cunha Santos G, Shepherd FA, Tsao MS. EGFR mutations and lung cancer. Annu Rev Pathol 2011;6:49-69.

16. Morris SW, Kirstein MN, Valentine MB, Dittmer KG, Shapiro DN Saltman DL, Look AT. Fusion of kinase gene, ALK, to a nucleolar protein gene, NPM, in non Hodgkin's lymphoma. Science 1994;263(5151):1281-4.

17. Shiota M, Nakamura S, Ichinohasama R, Abe M, Akagi T, Takeshita M, Mori N, Fujimoto J, Miyauchi J, Mikata A, Nanba K, Takami T, Yamabe H, Takano Y, Izumo T, Nagatani T, Mohri N, Nasu K, Satoh H, Katano $\mathrm{H}$, Fujimoto J, Yamamoto T, Mori S. Anaplastic large cell lymphomas expressing the novel chimeric protein p80NP/ALK: a distinct clinicopathologic entity. Blood 1995;86(5):1954-60.

18. Duyster J, Bai RY., Morris SW. Translocation involving anaplastic lymphoma kinase (ALK). Oncogene 2001;20(40):5623-37.

19. Amin HM, Lai R. Pathobiology of ALK+ anaplastic large-cell lymphoma. Blood 2007:110(7):2259-67.

20. Zhang $M$, Wang Q, Ding Y, Wang G, Chu Y, He X, Wu X, Shao YW, Lu K. CUX1-ALK, a novel ALK rearrangement that responds to crizotinib in non-small cell lung cancer. J Thorac Oncol 2018;13(11):1792-7.

21. Yang Y, Qin SK, Zhu J, Wang R, Li YM, Xie ZY, Wu Q. A rare STRN-ALK Fusion in lung adenocarcinoma identified using next-generation sequencing-based circulating tumor DNA profiling exhibits excellent response to crizotinib. Mayo Clin Proc Innov Qual Outcomes 2017;1(1):111-6.

22. Iyevleva AG, Raskin GA, Tiurin VI, Sokolenko AP, Mitiushkina NV Aleksakhina SN, Garifullina AR, Strelkova TN, Merkulov VO, Ivantsov AO, Kuligina ESh, Pozharisski KM, Togo AV, Imyanitov EN. Novel ALK fusion partners in lung cancer. Cancer Lett 2015;362(1):116-21.

23. Childress $M$, Himmelberg SM, Chen $H$, Deng W, Davies MA, Lovly CM. ALK fusion partners impact response to ALK inhibition: Differential effects on sensitivity, cellular phenotypes, and biochemical properties. Mol Cancer Res 2018;16(11):1724-36.

24. Soda M, Choi YL, Enomoto M, Takada S, Yamashita Y, Ishikawa S, Fujiwara S, Watanabe $\mathrm{H}$, Kurashina $\mathrm{K}$, Hatanaka $\mathrm{H}$, Bando M, Ohno S, Ishikawa Y, Aburtani H, Niki T, Sohara Y, Sugiyama Y, Mano H. Identification of the transforming EML4-ALK fusion gene in nonsmall cell lung cancer. Nature 2007;448:561-6.

25. Inamura $K$, Takeuchi $K$, Togashi $Y$, Nomura $K$, Ninomiya H, Okui $M$, Satoh Y, Okumura A, Nakagawa K, Soda M, Choi YL, Niki T, Mano H, Ishikawa Y. EML4-ALK fusion is linked to histological charasteristics in a subset of lung cancers. J Thorac Oncol 2008;3(1):13-7.

26. Pekar-Zlotin M, Hirsch FR, Soussan-Gutman L, Ilouze M, Dvir A Boyle T, Wynes M, Miller VA, Lipson D, Palmer GA, Ali SM, Dekel S, Brenner R, Bunn PA Jr, Peled N. Fluorescence in situ hybridization, immunohistochemistry, and next-generation sequencing for detection of EML-4-ALK rearrangement in lung cancer. Oncologist 2015;20(3):316-22.

27. Solomon B, Varella-Garcia M, Camidge DR. ALK gene rearrangements: a new therapeutic target in a molecularly defined subset of non-small cell lung cancer. J Thorac Oncol 2009;4(12):1450-4

28. Van der Wekken AJ, Pelgrim R, 't Hart N, Werner N, Mastik MF, Hendriks $L$, van der Hajden EHFM, Looijen-Salamon M, de Langen AJ, Staal-van den Brekel J, Riemersma S, van den Borne BE, Speel EJM, Dingemans AC, Hiltermann TJN, van den Berg A, Timens W, Schuuring E, Groen HJM. Dichotomous ALK-IHC Is a Better Predictor for ALK Inhibition Outcome than Traditional ALK-FISH in Advanced Non-Small Cell Lung Cancer. Clin Cancer Res 2017;23(15):4251-8.

29. U.S. Food \& Drug Administration. List of Cleared or Approved Companion Diagnostic Devices (In Vitro and Imaging Tools) [cited 2019 Oct 15]. Available from: https://www.fda.gov/medical-devices/ vitro-diagnostics/ list-cleared-or-approved-companion-diagnosticdevices-vitro-andimaging-tools

30. Rikova K, Guo A, Zeng Q, Possemato A, Yu J, Haack H, Nardone J, Lee K, Reeves C, Li Y, Hu Y, Tan Z, Stokes M, Sullivan L, Mitchell J, Wetzel R, Macneill J, Ren JM, Yuan J, Bakalarski CE, Villen J, Kornhauser JM, Smith B, Li D, Zhou X, Gygi SP, Gu TL, Polakiewicz RD, Rush J, Comb MJ. Global survey of phosphotyrosine signaling identifies oncogenic kinases in lung cancer. Cell 2007;131(6):1190-203.

31. Bargethon K, Shaw AT, Ou SH, Katayama R, Lovly CM, McDonald NT, Massion PP, Siwak-Tapp C, Gonzalez A, Fang R, Mark EJ, Batten JM, Chen H, Wilner KD, Kwak EL, Clark JW, Carbone DP, Ji H, Engelman JA, Mino-Kenudson M, Pao W, lafrate AJ. ROS1 rearrangement define a unique molecular class of lung cancers. J Clin Oncol 2012;30(8):86370.

32. Birchmeier C, Sharma S, Wigler M. Expression and rearrangement of the ROS1 gene in human glioblastoma cells. Proc Natl Acad Sci U S A 1987;84(24):9270-4.

33. Charest A, Lane K, Mc Mahon K, Park J, Preisinger E, Conroy H Housman D. Fusion of FIG to the receptor tyrosine kinase ROS in a glioblastoma with an interstitial del(6)(q21q21). Genes Chromosomes Cancer 2003;37(1):58-71.

34. Arai $Y$, Totoki $Y$, Takahashi $H$, Nakamura H, Hama N, Kohno T, Tsuta $K$ Yoshida A, Asamura J, Mutoh M, Hosoda F, Tsuda H, Shibata T. Mouse model for ROS1-rearranged lung cancer. PLoS One 2013;8(2):e56010.

35. Davies KD, Le AT, Theodoro MF, Skokan MC, Aisner DL, Berge EM, Terracciano LM, Cappuzzo F, Incarbone M, Roncalli M, Alloisio M, Santoro A, Camidge DR, Varella-Garcia M, Doebele RC. Identifying and targeting ROS1 gene fusions in non-small cell lung cancer. Clin Cancer Res 2012;18(17):4570-9.

36. Seo JS, Ju YS, Lee WC, Shin JY, Lee JK, Bleazard T, Lee J, Jung YJ, Kim JO, Shin JY, Yu SB, Kim J, Lee ER, Kang CH, Park IK, Rhee H, Lee SH, Kim Jl, Kang JH, Kim YT. The transcriptional landscape and mutational profile of lung adenocarcinoma. Genome Res 2012;22(11):2109-19.

37. Jun $\mathrm{HJ}$, Johnson $\mathrm{H}$, Bronson RT, de Feraudy S, White F, Charest A. The oncogenic lung cancer fusion kinase CD74-ROS activates a novel invasiveness pathway through E-Syt1 phosphorylation. Cancer Res 2012;72(15):3764-74

38. Ackermann CJ, Stock g, Tay R, Dawod M, Gomes F, Califano R Targeted therapy for RET-Rearranged Non-Small-Cell Lung Cancer: Clinicall development and future directions. Dovepress 2019;12:7857-64.

39. Takahashi M, Ritz J, Cooper GM. Activation of a novel human transforming gene, ret, by DNA rearrangement. Cell 1985;42(2):581-8.

40. Kohno T. Ichikawa H. Totoki Y. Yasuda K. Hiramoto M. Nammo T. Sakamoto H. Tsuta K. Furuta K. Shimada Y. Iwakawa R. Ogiwara H. Oike T. Enari M. Schetter AJ. Okayama H. Haugen A. Skaug V. Chiku S. Yamanaka I. Arai Y. Watanabe S. Sekine I. Ogawa S. Harris CC. Tsuda H. Yoshida T, Yokota J, Shibata T. KIF5B-RET fusions in lung adenocarcinoma. Nat Med 2012;18(3):375-377.

41. Ishizaka Y, Itoh F, Tahira T, Ikeda I, Sugimura T, Tucker J, Fertitta A, Carrano AV, Nagao M. Human ret proto-oncogene mapped to chromosome 10q11.2. Oncogene 1989;4(12):1519-21.

42. Lipson D, Capelletti M, Yelensky R, Otto G, Parker A, Jarosz M, Curran JA, Balasubramanian S, Bloon T, Brennan KW, Donahue A, Downing SR, Frampton GM, Garcia L, Juhn F, Mitchell KC, White E, White J, Zwirko Z, Perezt T, Nechushtan H, Soussan-Gutman L, Kim J, Sasaki H, Kim HR, Park SI, Ercan D, Sheehan CE, Ross JS, Cronin MT, Jänne PA, Stephens PJ. Identification of new ALK and RET gene fusions from colorectal and lung cancer biopsies. Nat Med 2012;18(3):382-4. 
43. Wang Y, Xu Y, Wang X, Sun C, Guo Y, Shao G, Yang Z, Qui S, Ma K RET fusion in advanced non-small-cell lung cancer and response to cabozatinib. Medicine (Baltimore) 2019;98(3):e14120.

44. Wang R, Hu H, Pan Y, Li Y, Ye T, Li C, Luo X, Wang L, Li H, Zhang Y, Li F, Lu Y, Lu Q, Xu J, Garfield D, Shen L, Ji H, Pao W, Sun Y, Chen H. RET fusion define a unique molecular and clinicopathologic subtype of non-small-cell lung cancer. J Clin Oncol 2012;30(35):4352-9.

45. Bronte G, Ulivi P, Verlicchi A, Cravero P, Delmonte A, Crino L. Targeting RET-rearranged non-small-cell lung cancer: future prospects. Lung cancer (Auckl) 2019;10:27-36.

46. Duh FM, Scherer SW, Tsui LC, Lerman MI, Zbar B, Schmidt L. Gene structure of the human MET proto-oncogene. Oncogene 1997;25(13):1583-6.

47. Wang Q, Yang S, Wang K, Sun SY. MET inhibitors for targeted therapy of EGFR-TKI-resistant lung cancer. J Hematol Oncol 2019;12(1):63.

48. Bottaro DP, Rubin JS, Faletto DL, Chan AM, Kmiecik TE, Vande Woude GF, Aaronson SA. Identification of the hepatocyte growth factor receptor as the c-met proto-oncogene product. Science 1991;251(4995):802-4

49. Ponzetto C, Bardelli A, Zhen Z, Marina F, dalla Zonca P, Giordano S. A multifunctional docking site mediates signaling and transformation by the hepatocyte growth factor/scatter factor receptor family. Cel 1994;77:261-71.

50. Fixman ED, Fournier TM, Kamikura DM, Naujokas MA, Park M Pathways downstream of Shc and Grb2 are required for cell transformation by the tpr-Met oncoprotein. J Biol Chem 1996;271:13116-22.

51. Boccaccio C, Gaudino G, Gambarotta G, Galimi F, Comoglio PM. Hepatocyte growth factor (HGF) receptor expression is inducible and is part of the delayed-early responce to HGF. J Biol Chem 1994;269:12846-51.

52. Organ SL, Tsao MS. An overview of the c-MET signaling pathway. Ther Adv Med Oncol 2011;3(1):7-19.

53. Califano R, Morgillo F, De Mello RA, Mountzios G. Role of mesenachy mal-epithelial transition amplification in resistence to anti-epidermal growth factor receptor agents. Ann Transl Med 2015;3(6):81.

54. Bäumer C, Fisch E, Wedler H, Reinecke F, Korfhage C. Exploring DNA quality of single cells for genome analysis with simultaneous wholegenome amplification. Sci Rep 2018;8(1):7476.

55. Ross K, Pailler E, Faugeroux V, Taylor M, Oulhen M, Auger N, Planchard D, Soria JC, Lindsay CR, Besse B, Vielh P, Farace F. The potential diagnostic power of circulating tumor cell anlysis for non-small-cell lung cancer. Expert Rev Mol Diagn 2015;15(12):1605-29.

56. Sorber L, Zwaenpoel K, Deschoolmeester V, Van Schii PE, Van Meerbeeck J, Lardon F, Rolfo C, Pauwels P. Circulating cel-free nucleic acids and platelets as a liquid biopsy in the provision of personalized therapy for lung cancer patients. Lung cancer 2017;107:100-7.

57. Cui S, Zhang W, Xiong L, Pan F, Niu Y, Chu T, Wang H, Zhao Y, Jiang L. Use of capture-based next-generation sequencing to detect ALK fusion in plasma cell-free DNA of patients with non-small-cell lung cancer. Oncotarget 2017;8(2):2771-80.

58. Lindquist KE, Karlsson A, Levéen $P$, Brunnström $H$, Reuterswärd $C$ Holm K, Jönsson M, Annersten K, Rosengren F, Jirström K, Kosieradzk J, Ek L, Borg A, Planck M, Jönsson G, Staaf J. Clinical Framework for next generation sequencing based analysis of treatment predictive mutationst and multiplexed gene fusion detection in non-small cell lung cancer. Oncotarget 2017;8(21):34796-810.

59. Frampton GM, Ali SM, Rosenzweig M, Chmielecki J, Lu X, Bauer TM, Akimov M, Bufill JA, Lee C, Jentz D, Hoover R, Ou SH, Salgia R, Brennan T, Chalmers ZR, Jaeger S, Huang A, Elvin JA, Erlich R, Fichtenholz A, Gowen KA, Greenbowe J, Johnson A, Khaira D, McMahon C, Sanford EM, Roels S, White J, Greshock J, Schlegel R, Lipson D, Yelensky R, Morosini D, Ross JS, Collisson E, Peters M Stephens PJ, Miller VA. Activation of MET via diverse exon 14 splicing alterations occurs in multiple tumor typer and confers clinica sensitivity of MET inhibitors. Cancer Discov 2015;5(8):850-9.

60. Haynes BC, Blinder RA, Cardwell RD, Zeigler R, Gokul S, Thibert JR, Chen L, Fujimoto J, Papadimitrakopoulou VA, Wistuba II, Latham GJ. An Integrated Next-Generation Sequencing System for analyzing DNA Mutations, Gene fusions, and RNA Expression in Lung Cancer. Transl Oncol 2019;12(6):836-45.

61. Di Resta C, Galbiati S, Carrera P, Ferrari M. Next-generation sequencing aproach for the diagnosis of human diseases: open challenges and new opportunities. EJIFCC 2018;29(1);4-14.
62. Tsoulos N, Papadopoulou E, Metaxa-Mariatou V, Tsaousis G, Efstathiadou C, Tounta G, Scapeti A, Bourkoula E, Zarogoulidis P, Pentheroudakis G, Kakolyris S, Boukovinas I, Papakotoulas $P$, Athanasiadis E, Floros T, Koumarianou A, Barbounis V, Dinischiotu A, Nasioulas G. Tumor molecular profiling of NSCLC patients using next generation sequencing. Oncol Rep 2017;38(6):3419-29.

63. Yi ES, Boland JM, Maleszewski JJ, Roden AC, Oliveira AM, Aubry MC, Erickson-Johnson MR, Caron BL, Li Y, Tang H, Stoddard S, Wampfler J, Kulig K, Yang P. Correlation of IHC and FISH for ALK gene rearrangement in non-small call lung carcinoma: IHC score algorithm for FISH. J Thorac Oncol 2011;6(3)459-65.

64. Luciani F, Bull RA, Lloyd AR. Next generation deep sequencing and vaccine design: today and tommorrow. Trends in Biotech 2012;30(9):443-52.

65. Velizheva NP, Rechsteiner MP, Valtcheva N, Freiberger SN, Wong CE, Vrug B, Zhong Q, Wagner U, Moch H, Hillinger S, Schmitt-Opitz I, Soltermann A, Wild PJ, Tischler V. Targeted next-generation-sequencing for reliable detection of targetable rearrangements in lung adenocarcinoma-a single center retrospective study. Pathol, Res Pract 2018;214(4):572-8.

66. Clavé S, Rodon N, Pijuan L, Diaz O, Lorenzo M, Rocha P, Taus Á, Blanco R, Boech-Barrera J, Reguart N, de la Torre N, Oliveras G, Espinet B, Bellosillo B, Puig X, Arriola E, Salido M. Next-generation sequencing for ALK and ROS1 rearrangement detection in patients with nonsmall-cell-lung cancer: Implications of FISH-positive patterns. Clin Lung Cancer 2019;20(4),e421-e429.

67. Scattone A, Catino A, Schirosi L, Caldarola L, Tommasi S, Lacalamita R, Montagna ES, Galetta D, Serio G, Zito FA, Mangia A. Discordance between FISH, IHC, and NGS Analysis of ALK Status in Advanced Non-Small Cell Lung Cancer (NSCLC): a Brief Report of 7 Cases. Transl Oncol 2019;12(2):389-95.

68. Watkins NA, Charames GS. Implementing Next-Generation Sequencing in Clinical Practice. The Journal of Applied Laboratory Medicine 2018;3(2):338-41.

69. Ju YS, Lee WC, Shin JY, Lee S, Bleazard T, Won JK, Kim YT, Kim JI, Kang JH, Seo JS. A transforming KIF5B and RET gene fusion in lung adenocarcinoma revealed from whole-genome and transcriptome sequencing. Genome Res 2012;22(3):436-45.

70. Borrelli N, Giannini R, Proietti A, Ali G, Pelliccioni S, Niccoli C, Lucchi M, Melfi F, Mussi A, Basolo F, Fontanini G. KIF5B/RET fusion gene analysis in a selected series of cytological specimens of EGFR, KRAS and EML4-ALK wild-type adenocarcinomas of the lung. Lung Cancer 2013;81(3):377-81.

71. Tran H, Zhang J, Vasquez M, Fossella F, Simon G, Tsao A, Gibbons DL, Elamin Y, Banks K, Lanman R, Papadimitrakopoulou V, Heymach J. Retrospective review clinical use of a cfDNA blood test for identification of targetable molecular alternations in patients with lung cancer. J Thorac Oncol 2017;12(1):s952.

72. Ferrara R, Auger N, Auclin E, Besse B. Clinical and translational implications of RET rearrangements in non-small cell lung cancer. J Thoracic Oncol 2018;13(1):27-45.

73. Heist RS, Shim HS, Gingipally S, Mino-Kenduson M, Le L, Gainor JF, Zheng Z, Aryee M, Xia J, Jia P, Jin H, Zhao Z, Pao W, Engelman JA, lafrate AJ. MET exon 14 skipping in non-small cell lung cancer. Oncologist 2016;21(4):481-6.

74. Kim EK, Kim KA, Lee CY, Kim S, Chang S, Cho BC, Shim HS. Molecular diagnostic assays and clinicopathologic implications of MET exon 14 skipping mutation in non-small-cell lung cancer. Clinical lung cancer 2019;20(1):e123-e32.

75. Ryška A, Buiga R, Fakirova A, Kern I, Olszewski W, Plank L, Seiwerth S, Toth E, Zivka E, Thallinger C, Zielinksi C, Brcic L. Non-small cell lung cancer in countries of central and southeastern europe: Diagnostic procedures and treatment reimbursement surveyed by the central european cooperative onkology group. Oncologist 2018;23(12):e152-e158.

76. Yoshida T, Oya Y, Tanaka K, Shimizu J, Horio Y, Kuroda H, Sakao Y, Hida T, Yatabe Y. Differential Crizotinib Response Duration Among ALK Fusion Variants in ALK-Positive Non-Small-Cell Lung Cancer. J Clin Oncol 2016;34(28):3383-9.

77. Kang J, Zhang X, Chen H, Zhou Q, Tu H, Li WF, Wu YL, Yang J. Uncommon ALK fusion partners in advanced ALK-positive nonsmall-cell lung cancer. J Clin Oncol 2018;36(15):8561. 